Prepared under the auspices of the U.S. Agency for International Development

\title{
Water-Balance Simulations of Runoff and Reservoir Storage for the Upper Helmand Watershed and Kajakai Reservoir, Central Afghanistan
}

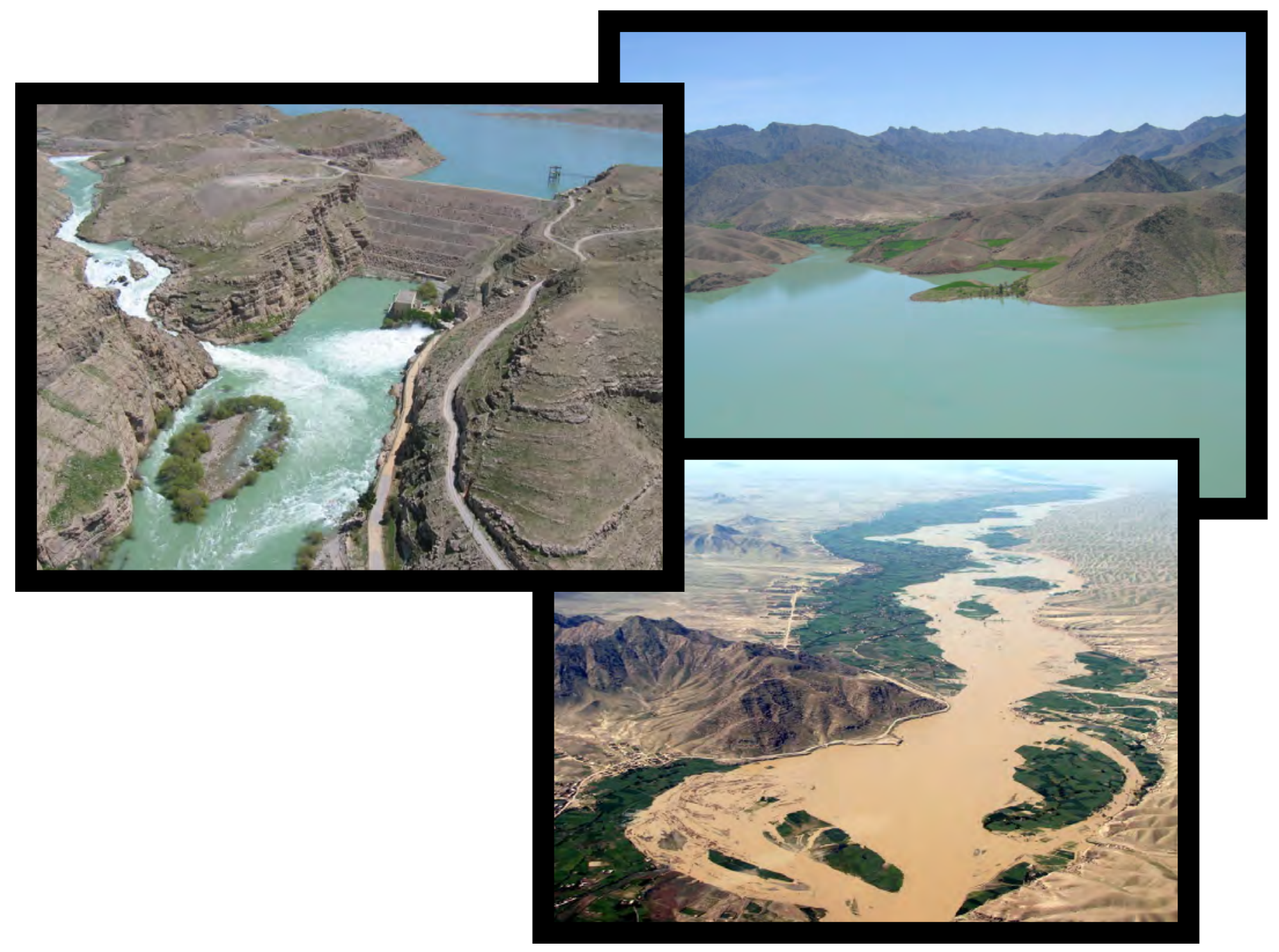

Scientific Investigations Report 2007-5148

U.S. Department of the Interior

U.S. Geological Survey 


\section{Covers.}

Front: Left and upper right photos, Kajakai Dam and Kajakai Reservoir, courtesy of Verne R. Schneider, U.S. Geological Survey; lower right photo, Helmand River, courtesy of Donald C. Houk, advisor to U.S. Agency for International Development

Back: Photo, Kajakai Reservoir, courtesy of John W. Whitney, U.S. Geological Survey 


\title{
Water-Balance Simulations of Runoff and Reservoir Storage for the Upper Helmand Watershed and Kajakai Reservoir, Central Afghanistan
}

\author{
By Kevin C. Vining and Aldo V. Vecchia
}

Prepared under the auspices of the U.S. Agency for International Development

This study was funded by Interagency Agreement 07C442100KB between the U.S. Agency for International Development and the U.S. Geological Survey.

Scientific Investigations Report 2007-5148

\author{
U.S. Department of the Interior \\ U.S. Geological Survey
}




\section{U.S. Department of the Interior DIRK KEMPTHORNE, Secretary}

\section{U.S. Geological Survey \\ Mark D. Myers, Director}

\section{U.S. Geological Survey, Reston, Virginia: 2007}

For product and ordering information:

World Wide Web: http://www.usgs.gov/pubprod

Telephone: 1-888-ASK-USGS

For more information on the USGS--the Federal source for science about the Earth, its natural and living resources, natural hazards, and the environment:

World Wide Web: http://www.usgs.gov

Telephone: 1-888-ASK-USGS

Any use of trade, product, or firm names is for descriptive purposes only and does not imply endorsement by the U.S. Government.

Although this report is in the public domain, permission must be secured from the individual copyright owners to reproduce any copyrighted materials contained within this report.

Suggested citation:

Vining, K.C., and Vecchia, A.V., 2007, Water-balance simulations of runoff and reservoir storage for the Upper Helmand watershed and Kajakai Reservoir, central Afghanistan: U.S. Geological Survey Scientific Investigations Report 2007-5148, 16 p. 


\section{Contents}

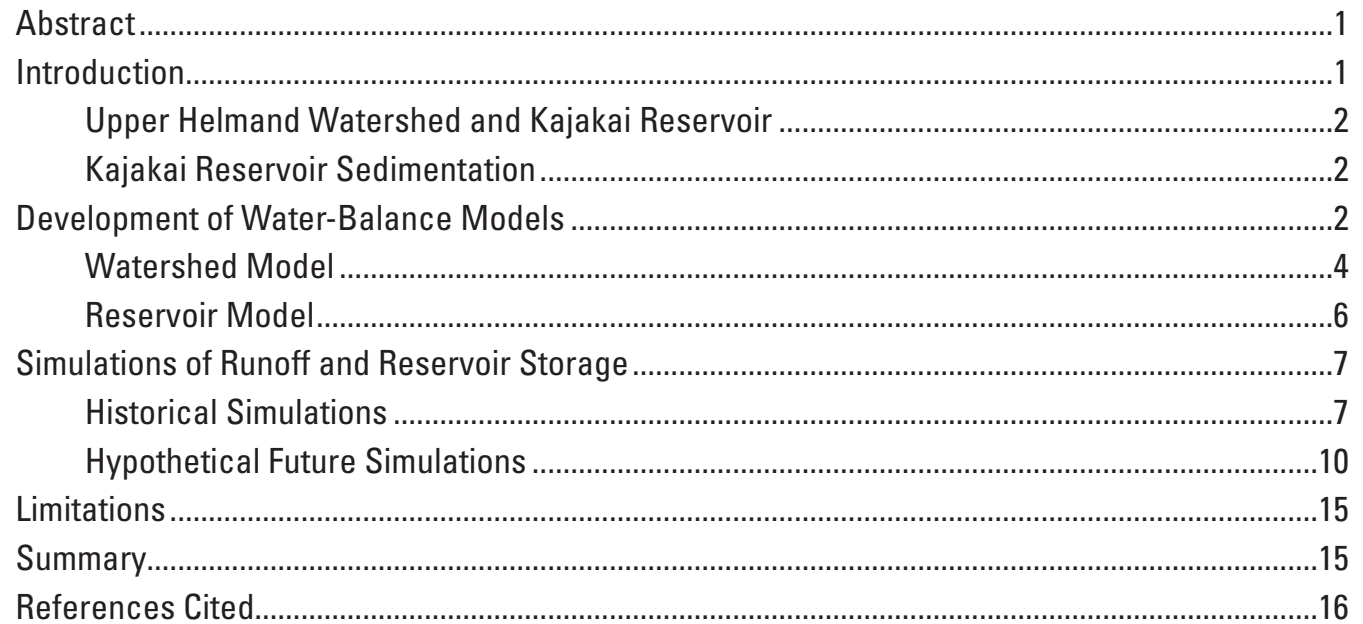

\section{Figures}

1. Map showing locations of the Upper Helmand watershed and Kajakai Reservoir, central Afghanistan. Adapted from Afghanistan Information Management Services (2006) and U.S. Geological Survey Landsat imagery obtained from Google ${ }^{\mathrm{TM}}$ Earth in 2007

2-8. Graphs showing:

2. Kajakai Reservoir sediment profiles for 1953 and 1968, and estimated sediment profile for 2006. Adapted from Perkins and Culbertson (1970).

3. Estimated percentiles of monthly precipitation for the Helmand River above Kajakai Reservoir near Dehraut gaging station for $A$, raw data and $B$, after incorporating snow accumulation and melt .

4. Measured and estimated monthly runoff for water years 1956-79 for the $A$, Helmand River above Kajakai Reservoir near Dehraut and $B$, Tirin River at Dehraut

5. Published and estimated storage volumes for 1968 and 2006 for Kajakai Reservoir, and model-fitted storage volumes for 1968, 2006, and 2057

6. Percentiles of generated monthly reservoir levels for a 36-month conditional simulation period and an initial reservoir level of 990 meters assuming $A$, existing downstream irrigation demand and $B$, a doubling of downstream irrigation demand

7. Examples of conditional reservoir traces for a severe drought (trace 304) and a moderate drought (trace 87) assuming existing irrigation demand

8. Percentiles of generated monthly reservoir levels for $A$, stationary conditions and double downstream irrigation demand with existing precipitation, temperature, and sedimentation; $B$, a 10-percent decrease in precipitation; $C$, a 2 -degree-Celsius increase in temperature; and $D, 50$ years of sedimentation. 


\section{Tables}

1. Estimated storage volumes for Kajakai Reservoir for 1968 and 2006

2. Monthly average precipitation, potential evapotranspiration, and net water-surface evaporation for Kajakai Reservoir ...

3. Assumed monthly water demand scenarios for Kajakai Reservoir.

\section{Conversion Factors}

SI to Inch/Pound

\begin{tabular}{lcl}
\hline Divide & By & To obtain \\
\hline millimeter $(\mathrm{mm})$ & Length & \\
meter $(\mathrm{m})$ & 25.4 & inch (in.) \\
kilometer $(\mathrm{km})$ & 0.3048 & foot (ft) \\
\hline & 1.609 & mile (mi) \\
\hline square meter $\left(\mathrm{m}^{2}\right)$ & Area & \\
hectare $($ ha) & 4,047 & acre \\
square kilometer $\left(\mathrm{km}^{2}\right)$ & 0.4047 & acre \\
square meter $\left(\mathrm{m}^{2}\right)$ & 0.004047 & acre \\
\hline & 0.0929 & square foot $\left(\mathrm{ft}^{2}\right)$ \\
\hline cubic meter $\left(\mathrm{m}^{3}\right)$ & Volume & \\
\hline & 1,233 & acre-foot (acre-ft) \\
\hline cubic meter per month $\left(\mathrm{m}^{3} / \mathrm{month}\right)$ & Flow rate & \\
\hline
\end{tabular}

Temperature in degrees Fahrenheit $\left({ }^{\circ} \mathrm{F}\right)$ may be converted to degrees Celsius $\left({ }^{\circ} \mathrm{C}\right)$ as follows:

$$
{ }^{\circ} \mathrm{C}=\left({ }^{\circ} \mathrm{F}-32\right) / 1.8
$$

Vertical coordinate information is referenced to Fairchild Aerial Surveys, Inc., U.S.A. triangulation stations established in 1953 (Perkins and Culbertson, 1970).

Horizontal coordinate information is referenced to Fairchild Aerial Surveys, Inc., U.S.A. triangulation stations established in 1953 (Perkins and Culbertson, 1970).

Elevation, as used in this report, refers to distance above an arbitrary datum (Perkins and Culbertson, 1970). 


\title{
Water-Balance Simulations of Runoff and Reservoir Storage for the Upper Helmand Watershed and Kajakai Reservoir, Central Afghanistan
}

\author{
By Kevin C. Vining and Aldo V. Vecchia
}

\begin{abstract}
A study was performed to provide information on monthly historical and hypothetical future runoff for the Upper Helmand watershed and reservoir storage in Kajakai Reservoir that could be used by Afghanistan authorities to make economic and demographic decisions concerning reservoir design and operation, reservoir sedimentation, and development along the Helmand River. Estimated reservoir volume at the current spillway elevation of $1,033.5$ meters decreased by about 365 million cubic meters from 1968 to 2006 because of sedimentation. Water-balance simulations indicated a good fit between modeled and recorded monthly runoff at the two gaging stations in the watershed for water years 1956-79 and indicated an excellent fit between modeled and recorded monthly changes in Kajakai Reservoir storage for water years 1956-79. Future simulations, which included low starting reservoir water levels and a spillway raised to an elevation of 1,045 meters, indicated that the reservoir is likely to fill within 2 years. Although Kajakai Reservoir is likely to fill quickly, multiyear deficits may still occur. If future downstream irrigation demand doubles but future precipitation, temperature, and reservoir sedimentation remain similar to historical conditions, the reservoir would have more than a 50-percent chance of being full during April or May of a typical year. Future simulations with a 10-percent reduction in precipitation indicated that supply deficits would occur more than 1 in 4 years, on average, during August, September, or October. The reservoir would be full during April or May fewer than 1 in 2 years, on average, and multiyear supply deficits could occur. Increased sedimentation had little effect on reservoir levels during April through July, but the frequency of deficits increased substantially during September and October.
\end{abstract}

\section{Introduction}

The management of natural resources, especially water, is important for improving the economy and the livelihoods of people in Afghanistan. Rivers and reservoir storage of surface runoff from snowmelt and occasional rainfall in the mountainous regions of the country are major sources of water, but, because the terrain across much of the country is steep, rocky, and sparsely vegetated, flooding from rapid snowmelt and intense rainfall can pose a significant risk to life and property. As a consequence of regional turmoil in the late 20th century, many dams and canals used to control water for personal and municipal consumption, hydropower production, and irrigation are in need of improvements.

Many people in Afghanistan live beside rivers and reservoirs to maintain easy access to water (Favre and Kamal, 2005). During periods of low water levels, people moved to the shores and onto the sediment beds of Kajakai Reservoir on the Helmand River in central Afghanistan to farm and possibly reside (Blue, 2006). Proposed economic development and future improvements to Kajakai Dam may include increases in reservoir storage for increased hydropower production and downstream irrigation. Increased reservoir water volumes and water levels could necessitate the resettlement of people who live near the reservoir, possibly requiring considerable expenditures by Afghanistan government agencies. To investigate the effects that proposed improvements to Kajakai Dam might have on reservoir storage, a study was conducted by the U.S. Geological Survey (USGS), in cooperation with the U.S. Agency for International Development, to simulate monthly runoff for the Upper Helmand watershed and reservoir storage in Kajakai Reservoir using historical streamflow and climate data and hypothetical future climate conditions in water-balance models. The purpose of this report is to provide Afghanistan authorities with information on historical and possible future monthly runoff from the Upper Helmand watershed and monthly water storage in Kajakai Reservoir that could be used to make economic and demographic decisions concerning reservoir design and operation, reservoir sedimentation, and development along the Helmand River. 


\section{Upper Helmand Watershed and Kajakai Reservoir}

The Upper Helmand watershed encompasses about 47,000 square kilometers and extends from the Koh-i Baba mountains west of Kabul to Kajakai Dam (Favre and Kamal, 2004; Whitney, 2006; fig. 1). The northern parts of the watershed are hilly to mountainous and generally have thin, rocky soils on mountain slopes and silty to sandy soils along streams (U.S. Agency for International Development, 1976). The southern parts of the watershed are hilly and generally have sandy to silty soils that have areas of gravel and rock. About 6 percent of the watershed is devoted to agriculture and the cultivation of fruit trees, but only about 2 percent of the watershed is irrigated for intensive agriculture; almost 90 percent of the watershed is rangeland (Favre and Kamal, 2004, 2005). The watershed has an arid to semi-arid climate and most precipitation falls at high elevations during October through May (U.S. Agency for International Development, 1976). Annual precipitation ranges from about 150 to 800 millimeters, and annual potential evapotranspiration ranges from about 800 to 2,400 millimeters (U.S. Agency for International Development, 1976; Favre and Kamal, 2004). A prolonged drought from about 1999 to 2005, which likely reduced streamflows in the Upper Helmand watershed and runoff to Kajakai Reservoir, resulted in the drying of wetlands on the Afghanistan-Iran border (Whitney, 2006).

Kajakai Reservoir, which is the major water body in the Upper Helmand watershed, formed after the completion of Kajakai Dam on the Helmand River in 1952 (Perkins and Culbertson, 1970; fig. 1). The main purpose of the reservoir was to supply irrigation water to areas downstream from Kajakai Dam. Hydropower-generation facilities were added to the dam in 1975. Planned improvements to the dam in the late 1970s included constructing spillway gates to impound water to an elevation of 1,045 meters, but construction was halted because of regional turmoil (U.S Army Corps of Engineers, written commun., 2005). Data on reservoir water volumes were collected for water years 1956-79 (October 1955 through September 1979) (Brigham, 1964; Democratic Republic of Afghanistan Ministry of Water \& Power, 1978, 1982; Democratic Republic of Afghanistan Ministry of Irrigation and Water Resources, 1985). Data that may have been collected after 1980 probably are sparse and difficult to obtain because of past turmoil and recent security concerns.

\section{Kajakai Reservoir Sedimentation}

Sediment deposition that has occurred since Kajakai Reservoir began filling in 1953 has altered the relation between reservoir water-level elevations and water-storage volumes. A topographic survey in 1953 indicated Kajakai Reservoir had an original volume of about 1,844 million cubic meters at the current spillway elevation of 1,033.5 meters (Perkins and Culbertson, 1970). (All vertical and horizontal coordinate information was referenced to triangulation stations established in 1953 by Fairchild Aerial Surveys, Inc., U.S.A.) In 1968, a sedimentation survey indicated the reservoir had lost about 7 percent of its volume at an elevation of 1,033.5 meters (Perkins and Culbertson, 1970). By 2005, continued sediment deposition likely had reduced the volume of the reservoir to an estimated 1,360 million cubic meters at the current spillway elevation (Whitney, 2006).

A Landsat image taken in about 2000 and obtained from Google ${ }^{\mathrm{TM}}$ Earth in 2007 (fig. 1) indicated possible sediment deposition upstream from a narrows in the reservoir (near kilometer 15) where farming plots and possible settlements appear (upstream from kilometer 25). Results from the 1968 sedimentation survey indicated that water depths of about 20 meters would have existed during 1968 near the farming plots and possible settlements if the water level was at the spillway elevation of 1,033.5 meters. The combination of satellite photography and past reservoir surveys indicates the elevation of sediment deposits in the far northern part of the reservoir (upstream from about kilometer 28) might at least equal the spillway elevation of $1,033.5$ meters. Using the reservoir surveys from 1968 and the estimated amount of sedimentation for 2005 (Whitney, 2006), a reservoir sediment profile for 2006 was estimated (fig 2). The sediment profiles for 1968 and 2006 were used to estimate reservoir volumes (table 1). Estimated reservoir volume at an elevation of 1,033.5 meters was about 1,350 million cubic meters in 2006, or a decrease of about 365 million cubic meters since 1968 . In 2006, the reservoir incremental volume between elevations of 1,030 and 1,045 meters was estimated to be about 1,140 million cubic meters (table 1 ), which compares well to an estimated 1,230 million cubic meters from a study that used a digital elevation model to determine reservoir incremental volumes (Blue, 2006).

\section{Development of Water-Balance Models}

Water-balance models can provide effective means for evaluating the sensitivity of water availability or flood risk to historical and hypothetical future climate conditions by relating runoff and reservoir storage to climatic inputs and hydrologic processes within a watershed. Monthly inflows to Kajakai Reservoir were modeled using estimates of monthly precipitation and temperature for the Upper Helmand watershed and runoff for two historical gaging stations on the Helmand and Tirin Rivers. Monthly changes in storage of Kajakai Reservoir were modeled to simulate possible reservoir sedimentation and storage-release scenarios. The effects of possible climate change and increasing downstream irrigation demand on water volumes in Kajakai Reservoir were modeled using hypothetical future scenarios that included changes in monthly precipitation and temperature and increases in reservoir sedimentation and downstream irrigation demand. 


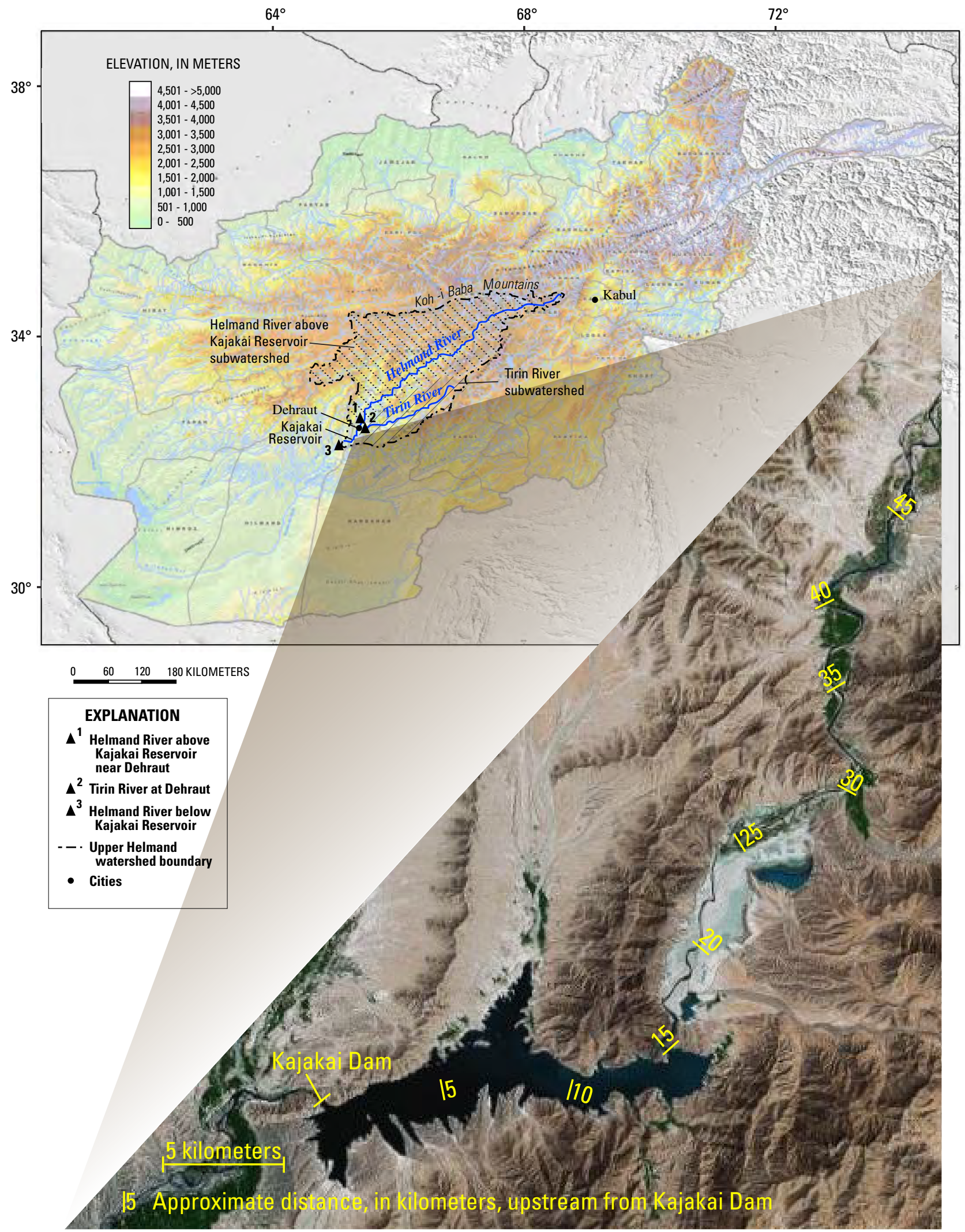

Figure 1. Locations of the Upper Helmand watershed and Kajakai Reservoir, central Afghanistan. Adapted from Afghanistan Information Management Services (2006) and U.S. Geological Survey Landsat imagery obtained from Google ${ }^{\mathrm{TM}}$ Earth in 2007. 


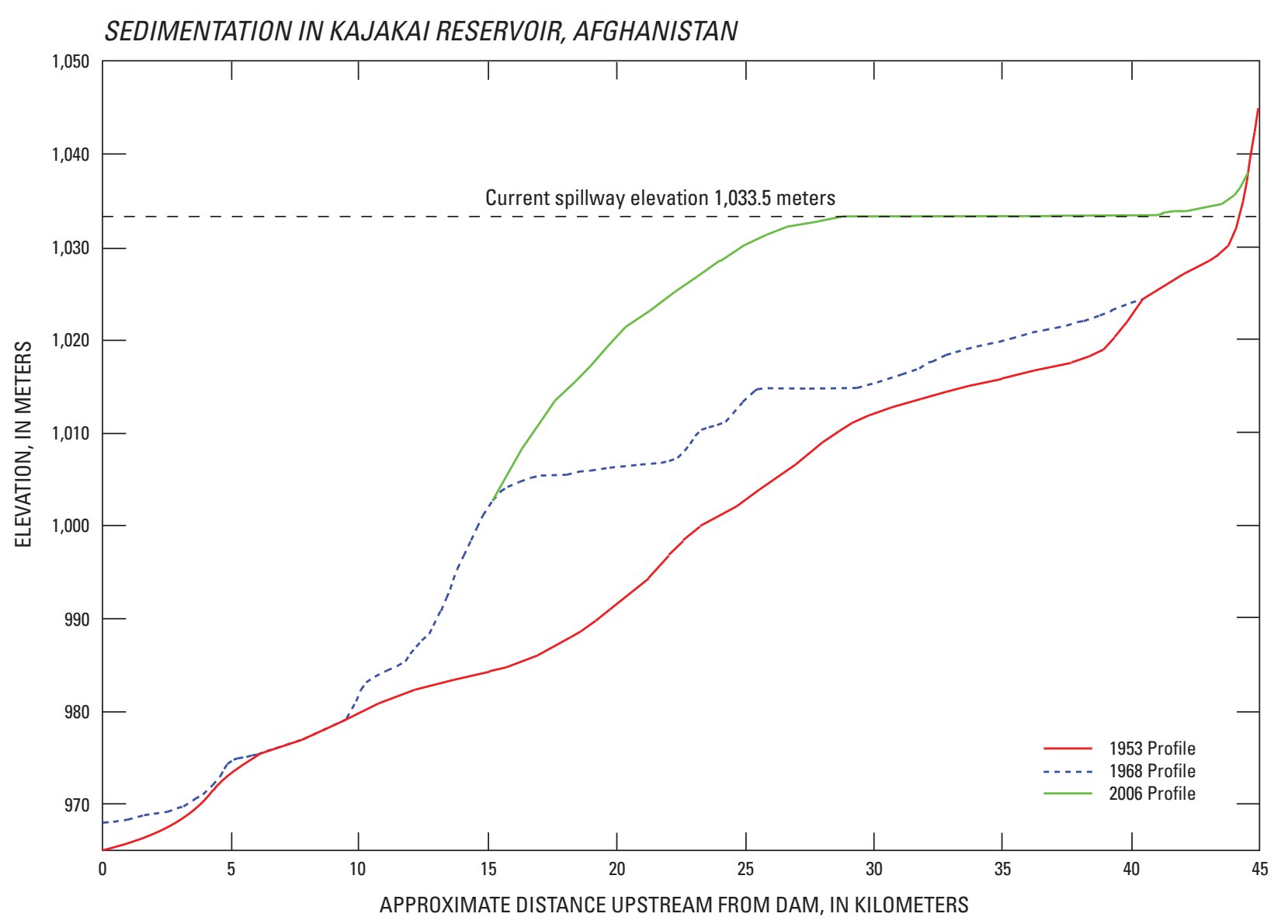

Figure 2. Kajakai Reservoir sediment profiles for 1953 and 1968, and estimated sediment profile for 2006. Adapted from Perkins and Culbertson (1970).

\section{Watershed Model}

The watershed water-balance model for estimating runoff from the Upper Helmand watershed is similar to a model described by Vandewiele and Elias (1995). The watershed model was divided into two sections, one for each of the subwatersheds associated with the gaging stations on the Helmand River above Kajakai Reservoir near Dehraut (hereinafter called the Helmand River above Kajakai Reservoir) and the Tirin River at Dehraut (hereinafter called the Tirin River) (fig. 1). Unless otherwise specified, all model variables are expressed as millimeters of water equivalent per square meter of subwatershed area.

The watershed model uses historical monthly streamflows, compiled by the USGS, for the two gaging stations for water years 1956-79 (Brigham, 1964; Democratic Republic of Afghanistan Ministry of Water \& Power, 1978, 1982; Democratic Republic of Afghanistan Ministry of Irrigation and Water Resources, 1985). Estimates of monthly average precipitation and temperature for the subwatershed of each gaging station for water years 1956-99 were provided by the
USGS Center for Earth Resources Observation and Science (EROS) and the University of California, Santa Barbara (UCSB). The monthly average precipitation and temperature data were computed from National Center for Atmospheric Research reanalysis data using downscaling methods that employed monthly climate data from Food and Agriculture Organization stations, International Water Management Institute long-term climate averages, and USGS HYDRO1k topographic information (Jodie Smith, Center for Earth Resources Observation and Science, oral commun., 2006). HYDRO1k is a geographic database developed to provide comprehensive and consistent global coverage of topographically derived data sets, including streams, drainage basins, and ancillary layers derived from the USGS 30 arc-second digital elevation model of the world (U.S. Geological Survey, 2007). The monthly average precipitation and temperature data used in the watershed model are available from the USGS North Dakota Water Science Center, Bismarck, N. Dak. Estimates of net evaporation for Kajakai Reservoir were calculated from average monthly precipitation and potential evaporation values for 1956-60 (U.S. Agency for International Development, 1976). 
Table 1. Estimated storage volumes for Kajakai Reservoir for 1968 and 2006.

\begin{tabular}{cccc}
\hline $\begin{array}{c}\text { Reservoir } \\
\text { elevation } \\
\text { (meters) }\end{array}$ & $\begin{array}{c}\text { 1968 capacity } \\
\text { (million cubic } \\
\text { meters) }\end{array}$ & $\begin{array}{c}\text { Estimated capacity } \\
\text { decrease, 1968-2006 } \\
\text { (million cubic } \\
\text { meters) }\end{array}$ & $\begin{array}{c}\text { Estimated } \\
\text { 2006 capacity } \\
\text { (million cubic } \\
\text { meters) }\end{array}$ \\
\hline 968 & 0 & 0 & 0 \\
970 & 2 & 0 & 2 \\
975 & 13 & 0 & 13 \\
980 & 42 & 0 & 42 \\
985 & 87 & 0 & 87 \\
990 & 145 & 0 & 145 \\
995 & 216 & 0 & 216 \\
1,000 & 299 & 0 & 299 \\
1,005 & 396 & 1 & 395 \\
1,010 & 521 & 17 & 504 \\
1,015 & 683 & 50 & 633 \\
1,020 & 893 & 115 & 778 \\
1,025 & 1,150 & 209 & 941 \\
1,030 & 1,462 & 302 & 1,160 \\
$1,033.5$ & 1,715 & 365 & 1,350 \\
1,035 & 1,824 & 365 & 1,459 \\
1,040 & 2,251 & 365 & 1,886 \\
1,045 & 2,664 & 365 & 2,299 \\
1,050 & 3,264 & 365 & 2,899 \\
\hline
\end{tabular}

For each subwatershed, the first step in the water-balance analysis was to compute the available water in the landscape, excluding reservoirs, at the beginning of the month:

$$
W(m)=S(m-1)+P(m),
$$

where

$$
\begin{gathered}
W(m) \quad \begin{array}{l}
\text { is the available water at the beginning of } \\
\text { month } m,
\end{array} \\
S(m-1) \quad \begin{array}{l}
\text { is the landscape storage remaining at the end } \\
\text { of the previous month, and }
\end{array} \\
P(m) \quad \begin{array}{l}
\text { is the monthly precipitation input after } \\
\text { incorporating snow accumulation and melt } \\
\text { (computed as described later). }
\end{array}
\end{gathered}
$$

Evapotranspiration (ET) was estimated as follows:

$$
e(m)=E(m)[1-\exp \{-\eta W(m) / E(m)\}],
$$

where

$e(m) \quad$ is estimated actual ET,

$E(m)$ is potential ET (computed using the

Thornthwaite (1948) method), and $\eta(0 \leq \eta \leq 1) \quad$ is a parameter that controls the rate at which available water is lost to ET.

Next, the precipitation input was divided into infiltration and direct runoff:

$$
I(m)=\left[P(m)-e_{0}(m)\right] \exp \{-\gamma \max [W(m)-e(m)-C, 0]\},
$$

and

$$
R_{D}(m)=P(m)-e_{0}(m)-I(m),
$$

where

$$
\begin{aligned}
& I(m) \text { is infiltration, } \\
& e_{0}(m)=e(m)[1-\exp \{-P(m) / e(m)\}] \\
& \text { is direct ET (the amount of ET lost prior to } \\
& \text { infiltration), } \\
& \gamma>0 \quad \text { is a parameter that controls the rate at which } \\
& \text { infiltration takes place, } \\
& C>0 \text { is a parameter for effective landscape storage } \\
& \text { capacity, and } \\
& R_{D}(m) \quad \text { is direct runoff (precipitation minus direct ET } \\
& \text { minus infiltration). }
\end{aligned}
$$

Total runoff for the month consists of direct runoff plus runoff that comes from landscape storage:

$$
R(m)=R_{D}(m)+(1-\lambda)\left[W(m)-e(m)-R_{D}(m)\right],
$$

where

$R(m)$ is total runoff for the month, and

$\lambda(0<\lambda<1)$ is a parameter that controls the rate at which landscape storage is lost to runoff.

The landscape storage for the end of the current month consists of the remaining storage:

$$
S(m)=\lambda\left[W(m)-e(m)-R_{D}(m)\right] .
$$

Equations 1 through 6 are repeated for the subsequent months $m+1, m+2, \ldots$.

The monthly precipitation input, which incorporated snow accumulation and melt, was computed from the monthly precipitation and temperature data supplied by EROS and an auxiliary landscape-storage variable. The precipitation input and auxiliary landscape-storage variable were computed using the following difference equations:

$$
P(m)=\alpha(m) S_{*}(m-1)+\alpha(m)[2-\alpha(m)] P_{*}(m),
$$

and

$$
S_{*}(m)=[1-\alpha(m)] S_{*}(m-1)+[1-\alpha(m)]^{2} P_{*}(m),
$$

where

$P(m) \quad$ is the monthly precipitation input after incorporating snow accumulation and melt; 


$$
\begin{aligned}
& \alpha(m)=\exp \{\min [T(m)-20,0] / 20\} ; \\
& T(m) \quad \text { is monthly temperature (averaged for the } \\
& \quad \text { subwatershed), in degrees Celsius; } \\
& S_{*}(m) \quad \text { is an auxiliary landscape-storage variable; and } \\
& P_{*}(m) \quad \text { is raw (untransformed) precipitation. }
\end{aligned}
$$

When monthly temperature exceeds 20 degrees Celsius (which generally occurs during July for the Helmand River above Kajakai Reservoir subwatershed and during June through August for the Tirin River subwatershed), then $\alpha(m)=1$, the auxiliary storage variable is zero, and $P(m)$ is equal to the precipitation for the current month. For the remaining months, $\alpha(m)<1$, the storage variable is positive, and part of the current month's precipitation goes into landscape storage.

Precipitation for a future simulation year was assumed to consist of precipitation for a randomly selected historical year, multiplied by a perturbation factor:

$$
P_{F}(j, m)=U_{j} P_{H}\left(Y_{j}, m\right),
$$

where

$$
\begin{aligned}
P_{F}(j, m) \quad \begin{array}{r}
\text { is future precipitation for simulation year } j \\
\text { and month } m,
\end{array} \\
U_{j} \quad \begin{array}{r}
\text { is a random multiplier with values between } \\
0.8 \text { and } 1.2,
\end{array} \\
P_{H}\left(Y_{j}, m\right) \quad \begin{array}{l}
\text { is historical precipitation for year } Y_{j} \text { and } \\
\text { month } m \text {, and }
\end{array} \\
Y_{j} \quad \begin{array}{l}
\text { designates a randomly selected historical year } \\
\text { from water years 1956-99. }
\end{array}
\end{aligned}
$$

The random multiplier was included so that years with drier or wetter conditions than indicated by the water years 1956-99 historical record could be generated. Years with 80 percent of the precipitation of the driest year during 1956-99 or 120 percent of the precipitation of the wettest year during 1956-99 are reasonable possibilities. To maintain the proper cross-correlation between generated runoff for both subwatersheds, the same historical year and multiplier were used for the gaging stations on the Helmand River above Kajakai Reservoir and on the Tirin River. Potential ET for each future simulation year consisted of potential ET for the same historical year used to generate precipitation.

The possible effect of climate change on runoff in the Upper Helmand watershed is not easily determined. Although most climate models predict increases in monthly temperature, monthly precipitation generally has greater year-to-year variability than monthly temperature and is more difficult to predict. However, some models indicate that, by about 2057 , a 15-percent or greater reduction in runoff could occur for central Afghanistan, primarily as a result of decreasing precipitation (Milly and others, 2005). The watershed water-balance model indicated that a 10 -percent reduction in precipitation resulted in a 17-percent decrease in runoff (results not shown). Therefore, to illustrate the sensitivity of future reservoir levels to hypothetical changes in precipitation, a scenario was used in which precipitation decreases by 10 percent from historical (water years 1956-99) precipitation amounts. To illustrate the sensitivity of reservoir levels to hypothetical changes in temperature, a scenario was used in which temperature increases by 2 degrees Celsius in each month compared to historical (water years 1956-99) temperatures. Also by about 2057, potential irrigated area below Kajakai Reservoir could increase from a current 234,000 hectares (Favre and Kamal, 2004) to an estimated 420,000 hectares (U.S. Army Corps of Engineers, written commun., 2005), resulting in a possible near doubling of irrigation demand.

\section{Reservoir Model}

The reservoir water-balance model for Kajakai Reservoir was developed to simulate the changes in reservoir storage using the data generated by the subwatershed water-balance models for the Helmand River above Kajakai Reservoir and the Tirin River gaging stations. Monthly reservoir contents and gaging station information for water years 1956-79 were used in the model.

Continuous elevation-capacity and elevation-area curves described by Vecchia (2002) were used to compute approximate storage volumes and surface areas for Kajakai Reservoir:

$$
V(h)=\frac{A_{\max }\left(h_{\max }-h_{\min }\right)}{p a}\left[a h^{*}+\frac{1}{2}(1-a)\left(1-\cos \left(\pi h^{*}\right)\right)\right]^{p},
$$

and

$$
\begin{array}{r}
A(h)=A_{\max }\left[a h^{*}+\frac{1}{2}(1-a)\left(1-\cos \left(\pi h^{*}\right)\right)\right]^{p-1} \\
{\left[1+\frac{1-a}{2 a} \pi \sin \left(\pi h^{*}\right)\right],}
\end{array}
$$

where

$$
\begin{gathered}
V \quad \text { is volume, in million cubic meters; } \\
h\left(h_{\min } \leq h \leq h_{\max }\right) \\
\quad \text { is elevation, in meters; } \\
h_{\min } \quad \text { is the minimum elevation; } \\
h_{\max } \quad \text { is the maximum elevation; } \\
A \quad \text { is area, in million square meters; } \\
A_{\max }=A\left(h_{\max }\right) \quad \text { is the maximum area; } \\
h^{*}=\left(h-h_{\min }\right) /\left(h_{\max }-h_{\min }\right) \\
\text { is standardized elevation }\left(0 \leq h^{*} \leq 1\right) \text {; and } \\
a>0 \text { and } p>1 \quad \text { are adjustable parameters. }
\end{gathered}
$$

The reservoir storage equations (eqs. 10 and 11) were fitted using the capacity estimates from table 1 as described later.

The monthly water-balance equation for Kajakai Reservoir expresses monthly changes in reservoir volume in terms of inflows, outflows, and net evaporation from the reservoir surface:

$$
R C(m)-R C(m-1)=Q_{\text {in }}(m)-Q_{\text {out }}(m)-E_{S}(m),
$$


where

$$
\begin{array}{cl}
R C(m) & \begin{array}{l}
\text { is reservoir volume at the end of month } m, \text { in } \\
\text { million cubic meters; }
\end{array} \\
Q_{\text {in }}(m) & \begin{array}{l}
\text { is inflow for month } m \text {, in million cubic } \\
\text { meters; }
\end{array} \\
Q_{\text {out }}(m) & \begin{array}{l}
\text { is outflow for month } m, \text { in million cubic } \\
\text { meters; and }
\end{array} \\
E_{S}(m) \quad \begin{array}{l}
\text { is net evaporation (evaporation minus } \\
\text { precipitation) for month } m \text {, in million cubic } \\
\text { meters. }
\end{array}
\end{array}
$$

Monthly inflows to the reservoir were assumed to equal the sum of monthly runoff for the Helmand River above Kajakai Reservoir and the Tirin River gaging stations. Ungaged runoff from the intervening drainage area downstream from the gages or around the reservoir was assumed to be negligible. Monthly outflows from the reservoir [which were obtained for water years 1956-79 from records for the gaging station on the Helmand River below Kajakai Reservoir (fig. 1) (Brigham, 1964; Democratic Republic of Afghanistan Ministry of Water \& Power, 1978, 1982; Democratic Republic of Afghanistan Ministry of Irrigation and Water Resources, 1985)] consisted of the sum of controlled discharge and spillway discharge, both of which are functions of reservoir level and reservoir operating rules. Net evaporation was approximated from monthly average precipitation and potential evapotranspiration by multiplying the surface area of the reservoir at the end of the previous month by a percentage of monthly average potential evapotranspiration minus precipitation (table 2). The monthly potential evapotranspiration percentage was estimated to be 0.8 on the basis of calculations of actual evapotranspiration from potential evapotranspiration (Shoemaker and Sumner, 2006) and estimates of annual evaporation at weather stations in southern Afghanistan (Favre and Kamal, 2004).

\section{Simulations of Runoff and Reservoir Storage}

Development of properly calibrated water-balance models for the Upper Helmand watershed and Kajakai Reservoir allows for important applications. The short historical record of streamflow and reservoir gage data (water years 1956-79) can be increased effectively using precipitation and temperature data from EROS and UCSB to estimate reservoir inflows and water levels after 1979 [climate data through 1999 are currently (2007) available, and data for more recent years are being developed]. The effects of hypothetical future climate change, downstream irrigation demand, reservoir design and operation, and sedimentation also can be determined. Generated future sequences, or traces, provide valuable information for evaluating the effects of future water-management decisions along the Helmand River.
Table 2. Monthly average precipitation, potential evapotranspiration, and net water-surface evaporation for Kajakai Reservoir.

\begin{tabular}{lccc}
\hline & $\begin{array}{c}\text { Precipitation } \\
\text { (millimeters) }\end{array}$ & $\begin{array}{c}\text { Potential } \\
\text { evapotranspiration } \\
\text { (millimeters) }\end{array}$ & $\begin{array}{c}\text { Net evaporation } \\
\text { (millimeters) }\end{array}$ \\
\hline January & 65 & 61 & -16 \\
February & 44 & 82 & 22 \\
March & 35 & 114 & 56 \\
April & 16 & 190 & 136 \\
May & 6 & 270 & 210 \\
June & 0 & 351 & 281 \\
July & 3 & 381 & 302 \\
August & 0 & 318 & 254 \\
September & 0 & 235 & 188 \\
October & 0 & 214 & 171 \\
November & 6 & 130 & 98 \\
December & 28 & 70 & 28 \\
\hline
\end{tabular}

${ }^{1}$ Net evaporation equals 0.8 times potential evapotranspiration minus precipitation.

\section{Historical Simulations}

The effect of the auxiliary storage equations (eqs. 7 and 8) on the precipitation input for the Helmand River above Kajakai Reservoir is shown in figure 3. Much of the precipitation that falls during November through March remains in storage (presumably in the form of snow or ice) and is released during April through June. Precipitation for July through October is essentially unaffected by the storage variable.

For both gaging stations, the water-balance parameters ( $\eta, \gamma, \lambda$, and $C$; eqs. $1-6$ ) were estimated by minimizing the sum of the squared differences between the base-10 logarithms of monthly runoff measured at the stream gage and monthly runoff computed using the water-balance model for water years 1956-79. A simple procedure, in which storage was first set equal to zero and then precipitation and potential ET for the first year (1956) were repeated for each year of a 5-year initialization period, was used to initialize the storage variable ( $S$ in eq. 1). The computed value of the storage variable for the end of the initialization period was used as the starting value $S(0)$.

The water-balance parameter estimates for the Helmand River above Kajakai Reservoir gaging station were $\eta=0.26$, $\gamma=0.40, \lambda=0.95$, and $C=146$. Measured and estimated runoff indicated a good model fit (fig. 4A). The correlation between log-transformed measured and estimated monthly runoff was $r=0.93$, and the correlation between untransformed measured and estimated monthly runoff was $r=0.91$. Mean monthly runoff was 3.8 percent higher for estimated 

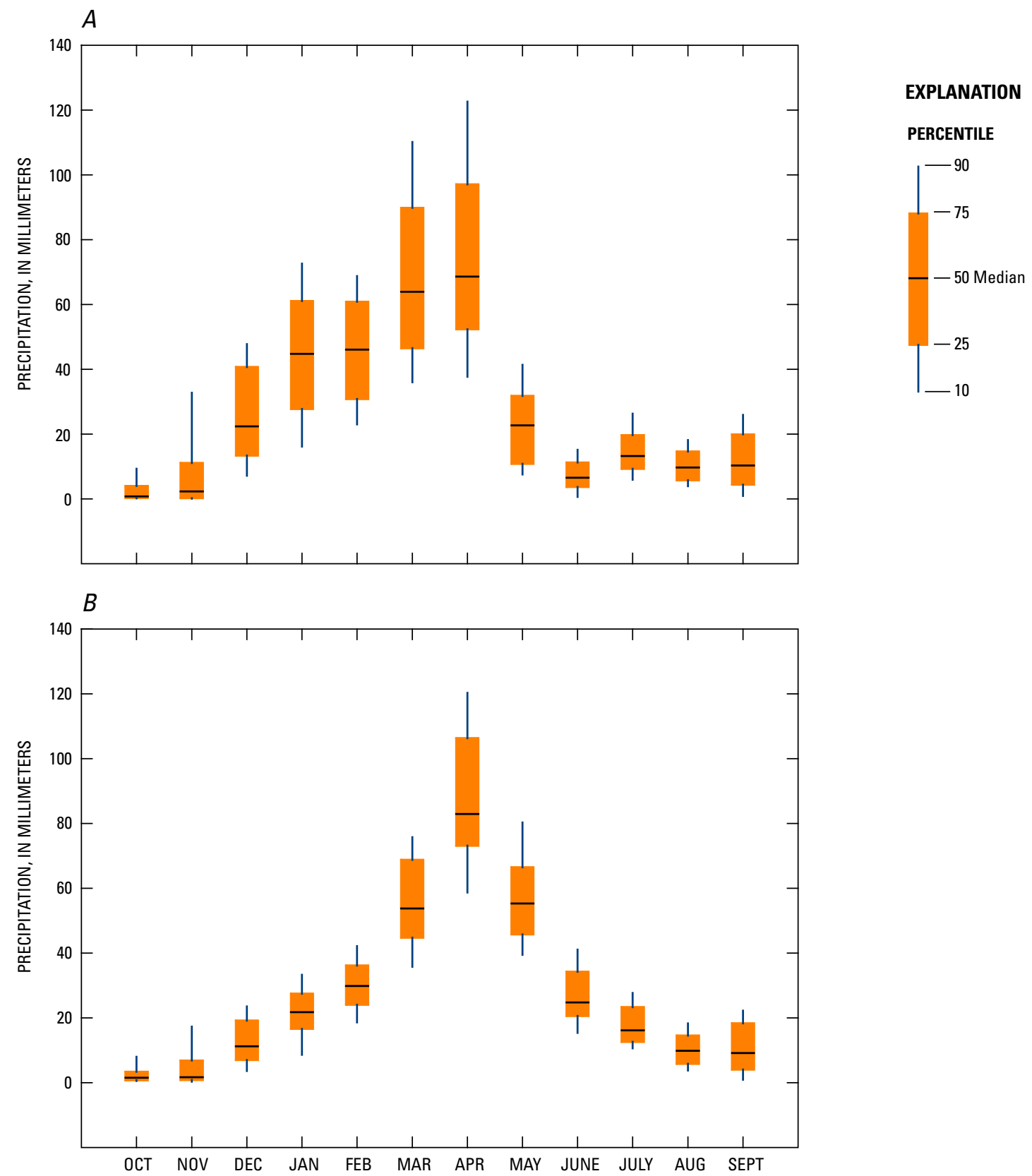

Figure 3. Estimated percentiles of monthly precipitation for the Helmand River above Kajakai Reservoir near Dehraut gaging station for $A$, raw data and $B$, after incorporating snow accumulation and melt.

runoff compared to measured runoff (487 million cubic meters per month compared to 469 million cubic meters per month). Close agreement between the means of measured and estimated runoff is an important consideration for computing reservoir volumes.

The water-balance parameter estimates for the Tirin River gaging station were $\eta=0.27, \gamma=0.14, \lambda=0.97$, and $C=175$. Measured and estimated runoff indicated a reasonable model fit (fig. 4B). The correlation between log-transformed mea- sured and estimated monthly runoff was $r=0.82$, and the correlation between untransformed measured and estimated monthly runoff was $r=0.81$. Mean monthly runoff was 3.5 percent higher for estimated runoff compared to measured runoff (43.1 million cubic meters per month compared to 41.6 million cubic meters per month). The combination of a smaller drainage area, less mountainous terrain, and less runoff made the estimation of runoff from the Tirin River more difficult than the estimation of runoff from the Helmand River. 

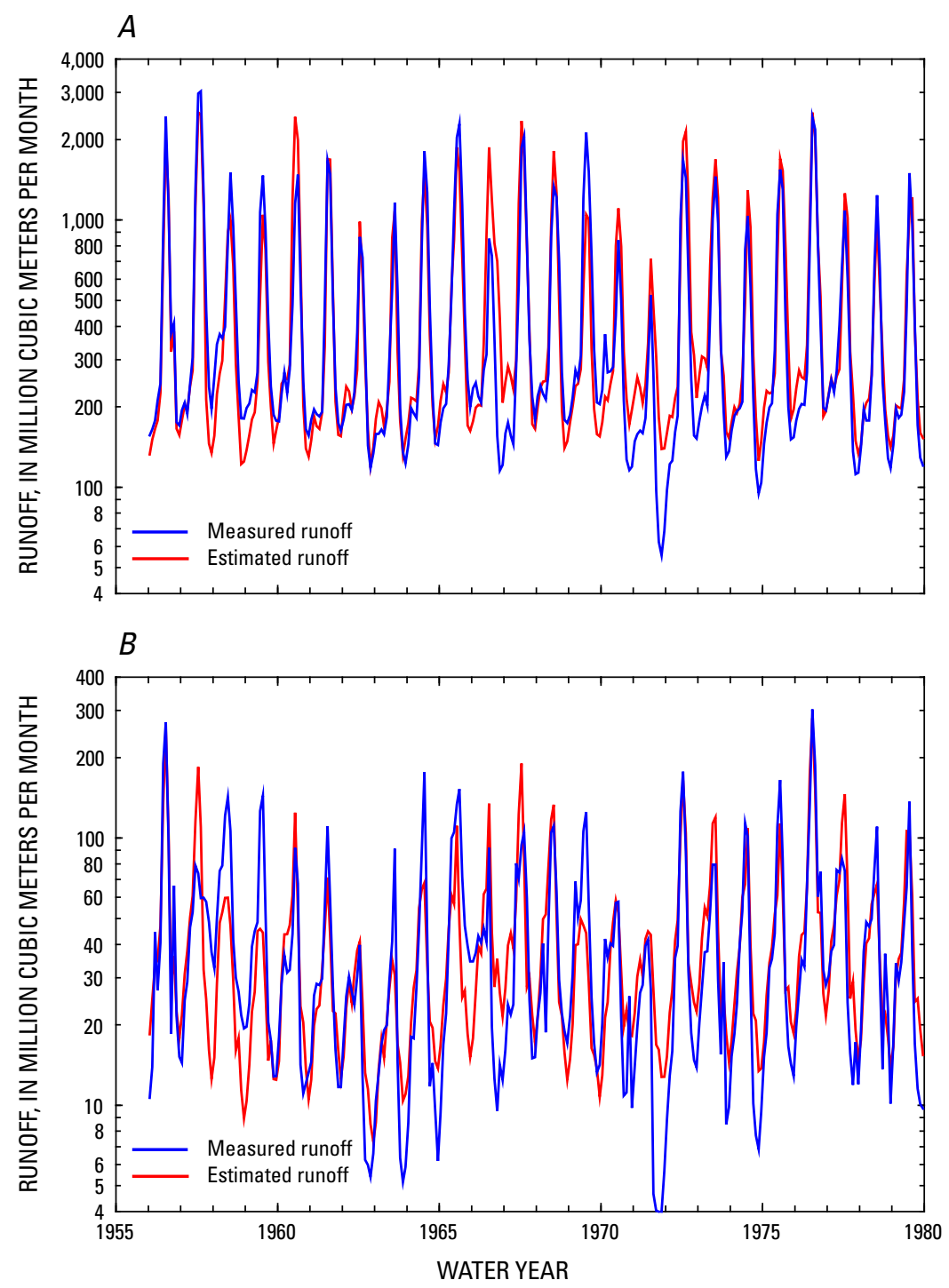

Figure 4. Measured and estimated monthly runoff for water years 1956-79 for the $A$, Helmand River above Kajakai Reservoir near Dehraut and $B$, Tirin River at Dehraut.

However, runoff from the Tirin River comprises only about 9 percent of total inflow for Kajakai Reservoir so inaccuracies in generated runoff from the Tirin River were not considered to be major influences on model results.

Coefficient values for the Kajakai Reservoir storage equations (eqs. 10 and 11) were $h_{\min }=968, h_{\max }=1,050$, $A_{\max }=130, p=2.67$, and $a=1.21$ for 1968 or $a=1.38$ for 2006. The values for $p$ and $a$ were selected to minimize the sum of the squared differences between the volumes computed using the equation and the estimated volumes from table 1. An increase in parameter $a$ simulates the effects of sedimentation by reducing the reservoir volume while keeping the maximum area constant. Comparisons between modelfitted and published and estimated storage volumes for 1968 and 2006 for Kajakai Reservoir show close agreement (fig. 5). The third curve in figure 5 shows what the model-fitted elevation-volume curve could be in 2057 with $a=1.66$ and assuming a sedimentation rate of 10 million cubic meters per year.

Equation 12 provided an excellent fit to the measured monthly changes in reservoir volume for water years 1956-79 (results not shown). The correlation coefficient between the fitted volume changes and the recorded volume changes was $r=0.986$, and the average difference between the measured and fitted volume changes was 1.2 million cubic meters per month. The excellent fit indicates potential ungaged sources or sinks, such as ground-water interaction or localized inflow, were negligible, and also indicates the 


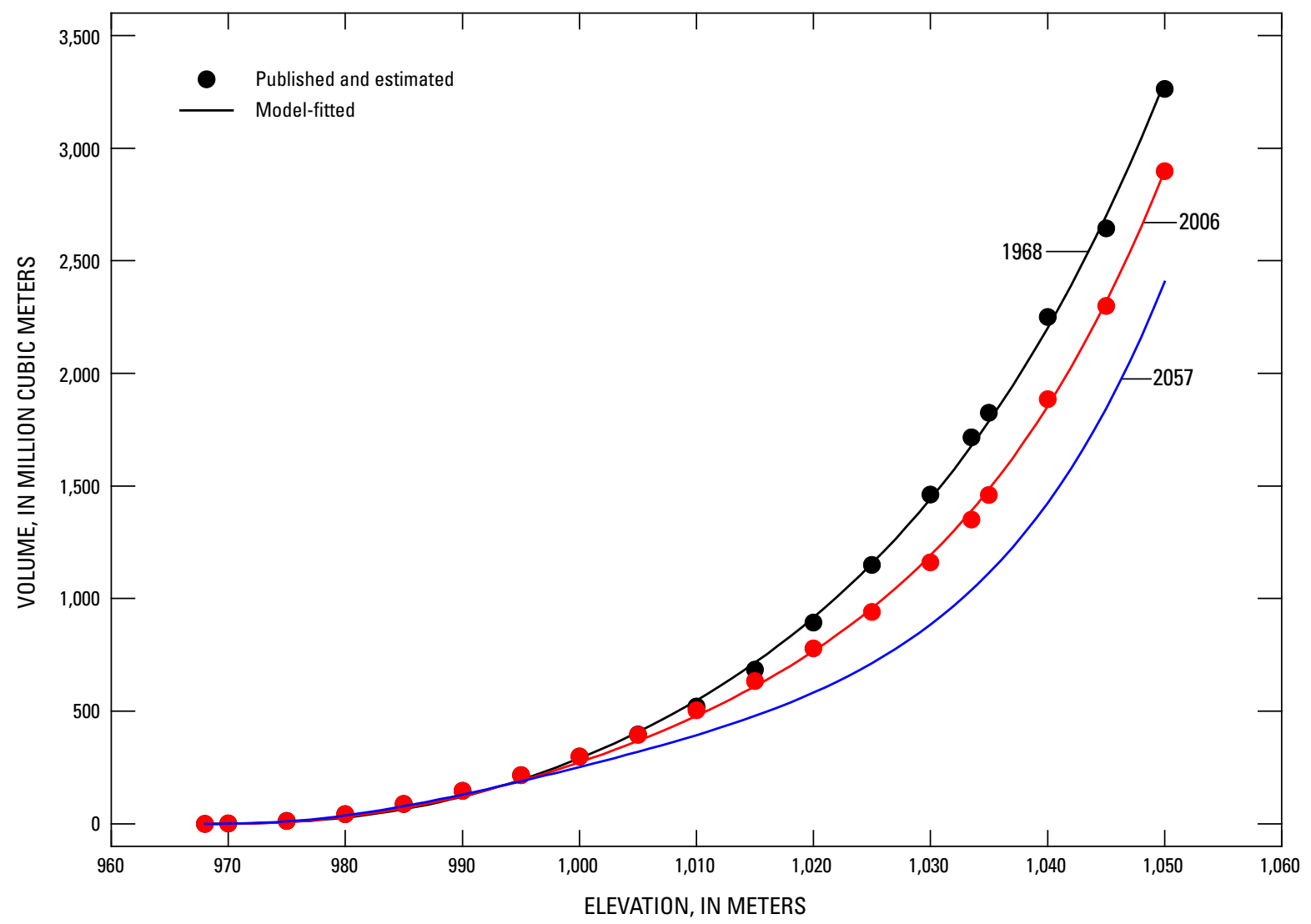

Figure 5. Published and estimated storage volumes for 1968 and 2006 for Kajakai Reservoir, and model-fitted storage volumes for 1968, 2006, and 2057.

method used for estimating evaporation from the reservoir surface was reasonable. The water balance was not particularly sensitive to potential errors in estimated evaporation from the reservoir surface. Doubling the monthly potential evaporation percentage for equation 12 resulted in an average difference between measured and fitted volume changes of 8.5 million cubic meters per month (compared with the previous value of 1.2 million cubic meters per month). Halving the monthly potential evaporation percentage for equation 12 resulted in an average difference of -3.5 million cubic meters per month.

\section{Hypothetical Future Simulations}

Given future sequences of precipitation and potential ET, assumed starting values for the watershed storage variable ( $S$ in eq. 1) for the upstream gaging stations, and an assumed starting level for the reservoir, equations 1 through 12 could be used to generate future inflows and lake levels for any scenario involving future reservoir design or operation. For the simulations described later, assumptions were that the spillway elevation would be raised to the proposed new level of 1,045 meters and that, provided the reservoir level stayed above a conservation elevation of 990 meters, controlled releases would be made to meet the monthly demand scenarios also described later. If meeting downstream irrigation demand in a particular month resulted in a generated reservoir level below 990 meters for the end of the month, the controlled releases were reduced to maintain a reservoir level of 990 meters, in which case downstream demands could not be met. If, after controlled releases, the reservoir level exceeded 1,045 meters at the end of the month, all excess volume above 1,045 meters was assumed to be released from the spillway.

The monthly demand scenarios (table 3 ) are similar to scenarios developed for previous studies (U.S Army Corps of Engineers, written commun., 2005). The first scenario uses existing estimated downstream irrigation demand and international streamflow requirements, and the second scenario assumes a doubling of estimated downstream irrigation demand and existing international streamflow requirements (U.S Army Corps of Engineers, written commun., 2005). 
Table 3. Assumed monthly water demand scenarios for Kajakai Reservoir.

\begin{tabular}{lcccc}
\hline & $\begin{array}{c}\text { Existing international } \\
\text { streamflow requirements } \\
\text { (million cubic meters) }\end{array}$ & $\begin{array}{c}\text { Existing irrigation } \\
\text { demand } \\
\text { (million cubic meters) }\end{array}$ & $\begin{array}{c}\text { Total demand for existing } \\
\text { conditions } \\
\text { (million cubic meters) }\end{array}$ & $\begin{array}{c}\text { Total demand for double } \\
\text { existing irrigation demand } \\
\text { (million cubic meters) }\end{array}$ \\
\hline January & 126 & 29 & 155 & 184 \\
February & 182 & 72 & 254 & 326 \\
March & 174 & 150 & 324 & 474 \\
April & 63 & 155 & 218 & 373 \\
May & 33 & 137 & 170 & 307 \\
June & 47 & 237 & 284 & 521 \\
July & 34 & 325 & 359 & 684 \\
August & 20 & 324 & 344 & 668 \\
September & 207 & 215 & 422 \\
October & 18 & 132 & 150 & 282 \\
November & 18 & 48 & 88 & 136 \\
December & 40 & 23 & 97 & 120 \\
\hline
\end{tabular}

Two simulation sets were generated for each demand scenario, with 1,000 randomly generated reservoir traces in each set. The first set, called conditional simulations, assumed a starting reservoir level (on October 1 of the first simulation year) of 990 meters and starting watershed storage equal to $0.25 C$, where $C$ is the estimated subwatershed landscape storage capacity from equation 3 . The purpose of the conditional simulations was twofold: (1) to determine how quickly the reservoir could fill after raising the spillway elevation to 1,045 meters, flooding residences or farmland near the reservoir; and (2) to determine the hypothetical severity of supply deficits during an extended drought. The second set of simulations, called stationary simulations, did not depend on starting reservoir level or watershed storage. The stationary simulations were obtained by running the simulation model for an initial 20-year adaptation period (after which the effect of the initial conditions became negligible) and then using the subsequent simulation years. The frequency distribution of the monthly reservoir level for any given month was stationary (the same for each subsequent year). The purpose of the stationary simulations was to determine the hypothetical effects of future climate change and reservoir sedimentation on the monthly frequency distributions of the reservoir levels.

The conditional simulations for existing downstream irrigation demand, climatic conditions, and sedimentation (fig. 6A) indicate that, even starting with very dry conditions, the reservoir is likely to fill within 2 years of raising the spillway elevation. At least 75 percent of the traces exceeded the spillway elevation during May of the second year, and at least 90 percent of the traces exceeded the spillway elevation during May of the third year. Even as early as May of the first year, at least 25 percent of the traces exceeded the spillway elevation. Conversely, only about 25 percent of the traces were below the conservation elevation during August and September of the first year, and fewer than 10 percent of the traces were below the conservation elevation each month beginning in November of the second simulation year.

The conditional simulations for increased downstream irrigation demand (fig. $6 B$ ) indicate that, even starting with very dry conditions and doubling the irrigation demand, there is more than a 50-percent chance the reservoir will fill within 2 years of raising the spillway elevation. At least 50 percent of the traces exceeded the spillway elevation during May of the second year, and almost 25 percent of the traces exceeded the spillway elevation during May of the first year. Comparing figures $6 A$ and $6 B$, monthly reservoir levels for years two and beyond tend to be lower and deficits tend to occur more often for increased than for existing downstream irrigation demand. For example, with increased irrigation demand, more than 25 percent of the traces were below the conservation elevation during September and October of the second year.

Although Kajakai Reservoir is likely to fill quickly, multiyear deficits may still occur. This point is illustrated with two conditional reservoir traces shown (fig. 7) for cases with existing irrigation demand (the same traces as used for figure $6 A$ ). These traces were selected by ranking the average annual supply deficit for a 5-year simulation period for all 1,000 traces from largest to smallest and selecting the trace with the $10^{\text {th }}$ largest deficit (trace 304 ) and the $100^{\text {th }}$ largest deficit (trace 87). Trace 304 had an average annual deficit of 294 million cubic meters per year, and trace 87 had an average annual deficit of 154 million cubic meters per year. Trace 304 

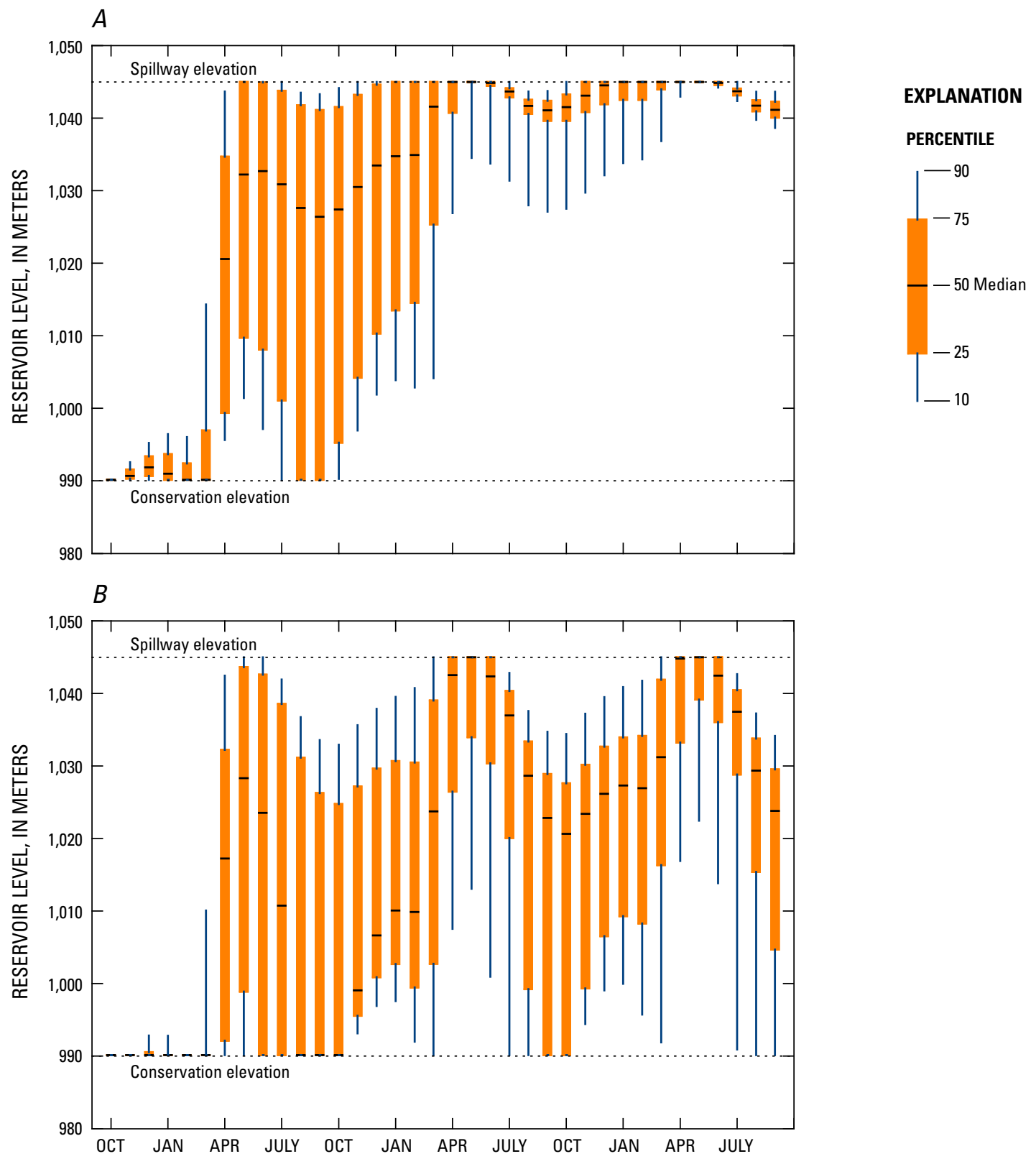

Figure 6. Percentiles of generated monthly reservoir levels for a 36-month conditional simulation period and an initial reservoir level of 990 meters assuming $A$, existing downstream irrigation demand and $B$, a doubling of downstream irrigation demand.

stays below 1,022 meters for more than 4 years before increasing to the raised spillway elevation, and trace 87 stays below 1,030 meters for more than 2 years before increasing to the raised spillway elevation. Although these filling events are not likely to occur every time the reservoir reaches a low elevation, over an extended period of time the chances of seeing a drought worse than indicated by trace 304 increases.

The following results of the stationary simulations are shown for double downstream irrigation demand only.
Stationary simulations for existing downstream irrigation demand are not shown because, as indicated by the previous discussion, there is a small chance existing demand cannot be met with the raised spillway elevation.

Judging by figure $8 A$, if future downstream irrigation demand doubles but future precipitation, temperature, and reservoir sedimentation remain similar to historical conditions, the reservoir would have more than a 50-percent chance of being full during April or May of a typical year. Therefore, 


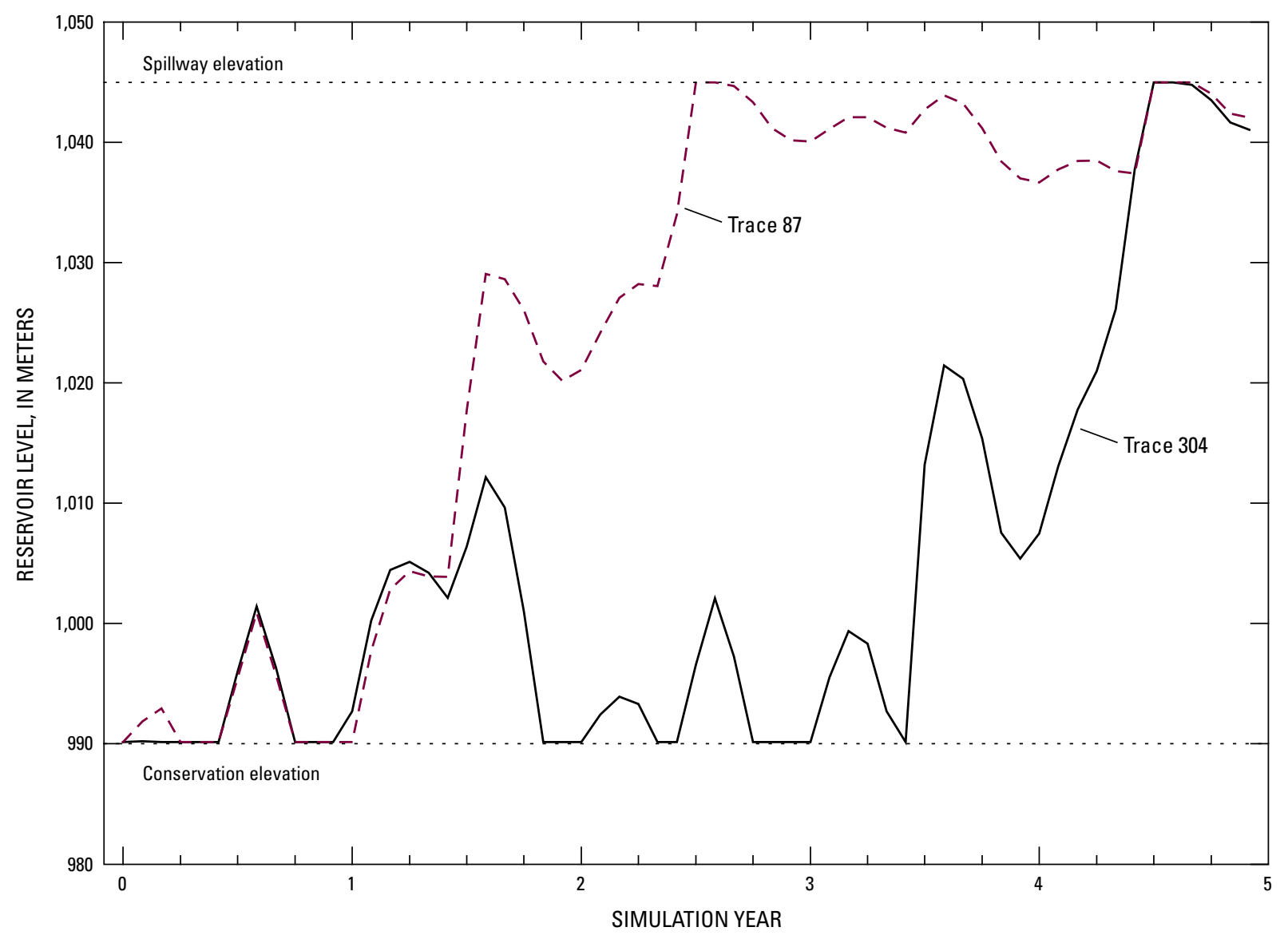

Figure 7. Examples of conditional reservoir traces for a severe drought (trace 304) and a moderate drought (trace 87) assuming existing irrigation demand.

the reservoir would fill more than 1 out of every 2 years on average. Supply deficits (as indicated by an elevation below 990 meters) would occur fewer than 1 out of 10 years during November through June and about 1 out of 10 years during July through October. Note, however, that even though the reservoir would fill 1 out of every 2 years on average, there may be long periods of time during which the reservoir stays well below the spillway elevation and substantial supply deficits could occur.

Another set of simulation runs was made to test the sensitivity of reservoir water levels to hypothetical precipitation reductions of 10 percent each month. Comparing the previous stationary simulations (fig. $8 A$ ) to the stationary simulations with a 10-percent reduction in precipitation (fig. $8 B$ ) indicates the reservoir levels are highly sensitive to a reduction in precipitation. With the lower precipitation, supply deficits would occur more than 1 in 4 years on average during August, September, or October and more than 1 in 10 years on average during February, March, June, or July. The reservoir would be full during April or May fewer than 1 in 2 years on average.
A third set of simulation runs was made to test the sensitivity of reservoir water levels to hypothetical temperature increases of 2 degrees Celsius each month and no changes in monthly precipitation. Comparing figures $8 A, 8 B$, and $8 C$, it is evident that reservoir levels are relatively insensitive to temperature increases as compared to precipitation decreases. The primary effect of increasing temperature was to lower the frequency distributions of reservoir levels somewhat during August, September, and October while the frequency distributions for the remaining months were not substantially affected. Although temperature increases resulted in increases in potential ET, landscape storage in the watershed generally was well below capacity during high-temperature months and, thus, actual ET did not increase substantially. Furthermore, the reservoir water balance was not particularly sensitive to changes in potential ET because net evaporation was small compared with average inflow and outflow volumes.

A final set of simulation runs was made to test the sensitivity of reservoir levels to hypothetical increased sedimentation and resulting loss in reservoir volume. The same traces used for figure $8 A$ were generated using the estimated 

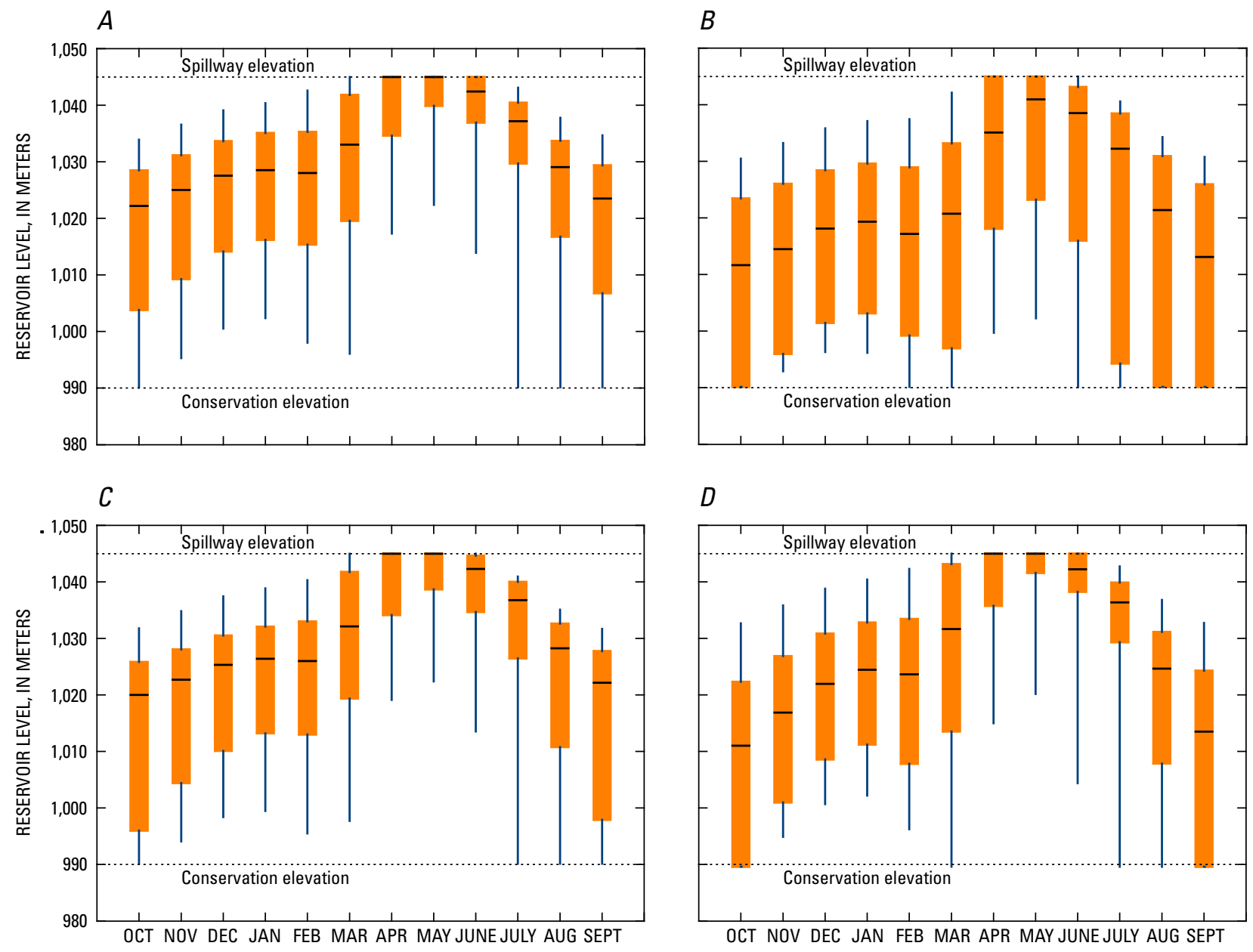

$D$

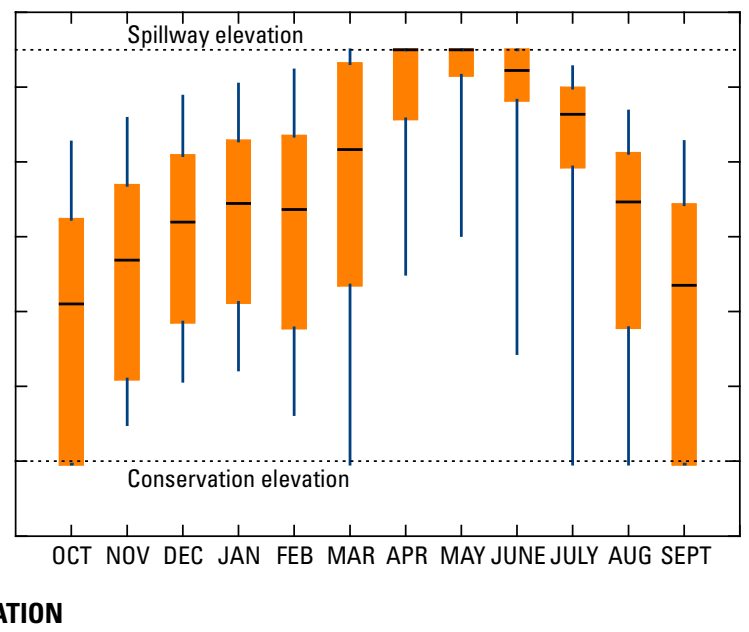

EXPLANATION

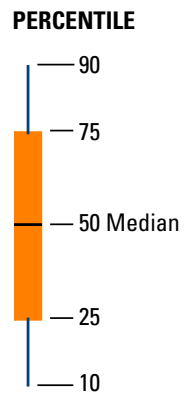

Figure 8. Percentiles of generated monthly reservoir levels for $A$, stationary conditions and double downstream irrigation demand with existing precipitation, temperature, and sedimentation; $B$, a 10-percent decrease in precipitation; $C$, a 2-degree-Celsius increase in temperature; and $D, 50$ years of sedimentation.

storage volumes for 2057 instead of 2006 as shown in figure 5. The reservoir volume at 1,045 meters was reduced by about 22 percent (from 2,300 million cubic meters to 1,800 million cubic meters) as a result of additional sedimentation. As seen by comparing figures $8 A$ and $8 D$, increased sedimentation had relatively little effect on the reservoir levels during April through July, but the frequency distributions were lowered during the remaining months as a result of the reduced storage volume. Increased sedimentation substantially increased the frequency of supply deficits during September and October, during which supply deficits occurred about 1 in 4 years on average compared to about 1 in 10 years on average, with existing sedimentation. 


\section{Limitations}

Historical data for streamflow stations in the Upper Helmand watershed and water levels for Kajakai Reservoir were limited to a relatively short period (water years 1956-79) and possibly did not include potential low or high streamflows. Sediment deposition that has occurred since Kajakai Reservoir began filling in 1953 has changed the original relation between reservoir water-level elevations and water-storage volumes. Without more recent reservoir survey information, the accuracy of the estimates used for the current elevation-capacity curve cannot be determined.

The climate data used in this study did not incorporate the drought conditions of 1999-2005, during which streamflows in the Helmand River were likely reduced and resulted in low water levels in Kajakai Reservoir. Although water-balance simulations using the climate data for water years 1956-99 indicated low reservoir water levels for 4 years or longer are possible, without a longer historical record it is difficult to estimate the probability of a drought such as 1999-2005 with any accuracy. No information was available on water levels in Kajakai Reservoir during the drought, but the presence of farming and possible settlements along the reservoir indicates water levels were low for several years.

Elevations discussed in this report were referenced to a datum of unknown accuracy and origin. Therefore, the elevations should not be interpreted as meters above sea level. The actual elevation of the reservoir surface cannot be determined until an accurate, well-documented benchmark can be established.

The precipitation and temperature data developed by EROS and UCSB represent the current state of the art for integrating climate reanalysis, GIS, and ground-based observations. However, without more ground-based precipitation measurements it is difficult to quantify the accuracy of the estimates. Estimating the spatial distribution of precipitation in mountainous terrain is difficult even in watersheds for which extensive ground-based observations are available. A statistically based water-balance model was used in this report instead of a deterministic rainfall-runoff model because accurate precipitation data at the spatial and temporal scales required for a deterministic model are not available for the Helmand watershed. The water-balance model should be refined and improved as more extensive data become available.

The effects that proposed modifications of Kajakai Dam might have on downstream flooding were not evaluated in this report. Such an evaluation would require a shorter time step, such as daily, than used in this report, and a downstream flowrouting model would need to be coupled with the reservoir model. The monthly time step used herein was the shortest feasible time step given the data and model limitations of this study.

\section{Summary}

Proposed economic development and future improvements to Kajakai Dam in central Afghanistan may include increases in reservoir storage for increased hydropower production and downstream irrigation. Increased reservoir water volumes and water levels could necessitate the resettlement of people who live near the reservoir, possibly requiring considerable expenditures by Afghanistan government agencies. A study was conducted by the U.S. Geological Survey, in cooperation with the U.S. Agency for International Development, to provide information on historical and hypothetical future monthly runoff from the Upper Helmand watershed and monthly water storage in Kajakai Reservoir that could be used by Afghanistan authorities to make economic and demographic decisions concerning reservoir design and operation, reservoir sedimentation, and development along the Helmand River.

Sediment deposition that has occurred since Kajakai Reservoir began filling in 1953 has altered the relation between reservoir water-level elevations and water-storage volumes. Using past reservoir surveys and the estimated amount of sedimentation for 2005, a reservoir sediment profile for 2006 was estimated. Estimated reservoir volume at the current spillway elevation of $1,033.5$ meters was about 1,715 million cubic meters for 1968 but only about 1,350 million cubic meters for 2006, or a decrease of about 365 million cubic meters.

Estimated runoff at the Helmand River above Kajakai Reservoir gaging station indicated a good fit with measured runoff; the correlation between log-transformed measured and estimated monthly runoff was $r=0.93$. Mean monthly runoff was 3.8 percent higher for estimated runoff compared to measured runoff. Estimated runoff at the Tirin River gaging station indicated a reasonable fit with measured runoff; the correlation between log-transformed measured and estimated monthly runoff was $r=0.82$. Mean monthly runoff was 3.5 percent higher for estimated runoff compared to measured runoff. Monthly volume changes for Kajakai Reservoir were modeled using estimates of monthly net reservoir-surface evaporation, runoff for two historical gaging stations upstream from the reservoir, and reservoir outflows for a historical gaging station downstream from Kajakai Dam. Results for water years 1956-79 indicated an excellent fit with measured volume changes; the correlation coefficient was $r=0.986$ and the average difference between the measured and fitted volume changes was 1.2 million cubic meters per month.

Simulations of hypothetical future levels of Kajakai Reservoir were generated with a spillway elevation of 1,045 meters and double the existing downstream irrigation demand. The simulations were conditioned on a low starting reservoir level. The future simulations indicated the reservoir is likely to fill within 2 years of raising the spillway elevation. Although Kajakai Reservoir is likely to fill quickly, multiyear deficits may still occur. 
If future downstream irrigation demand doubles but future precipitation, temperature, and reservoir sedimentation remain similar to historical conditions, the reservoir would have more than a 50-percent chance of being full during April or May of a typical year, and, during any given month, supply deficits would occur in less than about 1 out of every 10 years on average. If a 10-percent reduction in future precipitation occurs, supply deficits would occur more than 1 in 4 years on average during August, September, or October and more than 1 in 10 years on average during February, March, June, or July. The reservoir would be full during April or May fewer than 1 in 2 years on average, and substantial multiyear supply deficits could occur. If monthly temperatures increased by 2 degrees Celsius and monthly precipitation did not change, reservoir levels would be relatively unchanged except for a slight increase in the frequency of deficits during August through October. Increased sedimentation had little effect on reservoir levels during April through July, but the frequency of deficits increased substantially during September and October.

\section{References Cited}

Afghanistan Information Management Services, 2006, Afghanistan physical map: accessed May 2007 at http://www.aims.org.af

Blue, A.C., 2006, Kajakai Dam inundation study-Kajakai Dam and Reservoir, Helmand Province, Afghanistan: U.S. Army Corps of Engineers Report to U.S. Agency for International Development, September 2006, 23 p.

Brigham, R.H., 1964, Compilation of Hydrologic Data, Helmand River Valley, Afghanistan through September 1960: U.S. Geological Survey, 234 p.

Democratic Republic of Afghanistan Ministry of Water \& Power, 1978, Hydrological Yearbook 1961-1975, Part II - 4A Helmand River basin (Excluding Arghandab River basin) : Water and Soil Survey Department, Afghanistan Hydrologic Data Report RO 210, 244 p.

Democratic Republic of Afghanistan Ministry of Water \& Power, 1982, Hydrological Yearbook 1976-1978, Part II Rivers of Helmand Basin: Water and Soil Survey Department, Afghanistan Hydrologic Data Report RO 212, $146 \mathrm{p}$.

Democratic Republic of Afghanistan Ministry of Irrigation and Water Resources, 1985, Hydrological Yearbook 1979-1980, Part (I and II) Rivers of Indus and Helmand Basin (Kabul, Khuram, Helmand and Ghazni): Institute of Water Resources Development, Afghanistan Hydrologic Data Report RO 211, 131 p.
Favre, R., and Kamal, G.M., 2004, Watershed atlas of Afghanistan: Afghanistan Information Management Service, Kabul, Afghanistan, 183 p.

Favre, R., and Kamal, G.M., 2005, Watershed atlas of Afghanistan-Book 2, Watershed maps: Afghanistan Information Management Service, Kabul, Afghanistan, 145 p.

Milly, P.C.D., Dunne, K.A., and Vecchia, A.V., 2005, Global pattern of trends in streamflow and water availability in a changing climate: Nature, v. 438, no. 17 , p. 347-350.

Perkins, D.C., and Culbertson, J.K., 1970, Hydrographic and sedimentation survey of Kajakai Reservoir, Afghanistan: U.S. Geological Survey Water-Supply Paper 1608-M, 43 p.

Shoemaker, W.B., and Sumner, D.M., 2006, Alternate corrections for estimating actual wetland evapotranspiration from potential evapotranspiration: Wetlands, v. 26, no. 2, p. 528-543.

Thornthwaite, C.W., 1948, An approach toward a rational classification of climate: Geographical Review v. 38, p. 55-94.

U.S. Agency for International Development, 1976, Helmand River Basin-Soil and water survey study report: Open-File Report in Kabul, Afghanistan, 180 p.

U.S. Geological Survey, 2007, HYDRO1k Elevation Derivative Database: accessed May 2007 at http://edc.usgs. gov/products/elevation/gtopo30/hydro/index.htm

Vandewiele, G.L., and Elias, A., 1995, Monthly water balance of ungauged catchments obtained by geographical regionalization: Journal of Hydrology, v. 170, p. 277-291.

Vecchia, A.V., 2002, Simulation of a proposed emergency outlet from Devils Lake, North Dakota: U.S. Geological Survey Water-Resources Investigations Report 02-4042, 129 p.

Whitney, J.W., 2006, Geology, water, and wind in the lower Helmand Basin, southern Afghanistan: U.S. Geological Survey Scientific Investigations Report 2006-5182, 40 p. 
Prepared by the Helena Publishing Service Center.

For more information concerning the research in this report, contact:

Director, U.S. Geological Survey

North Dakota Water Science Center

821 East Interstate Avenue

Bismarck, North Dakota 58503

(701) 250-7400

http://nd.water.usgs.gov/ 


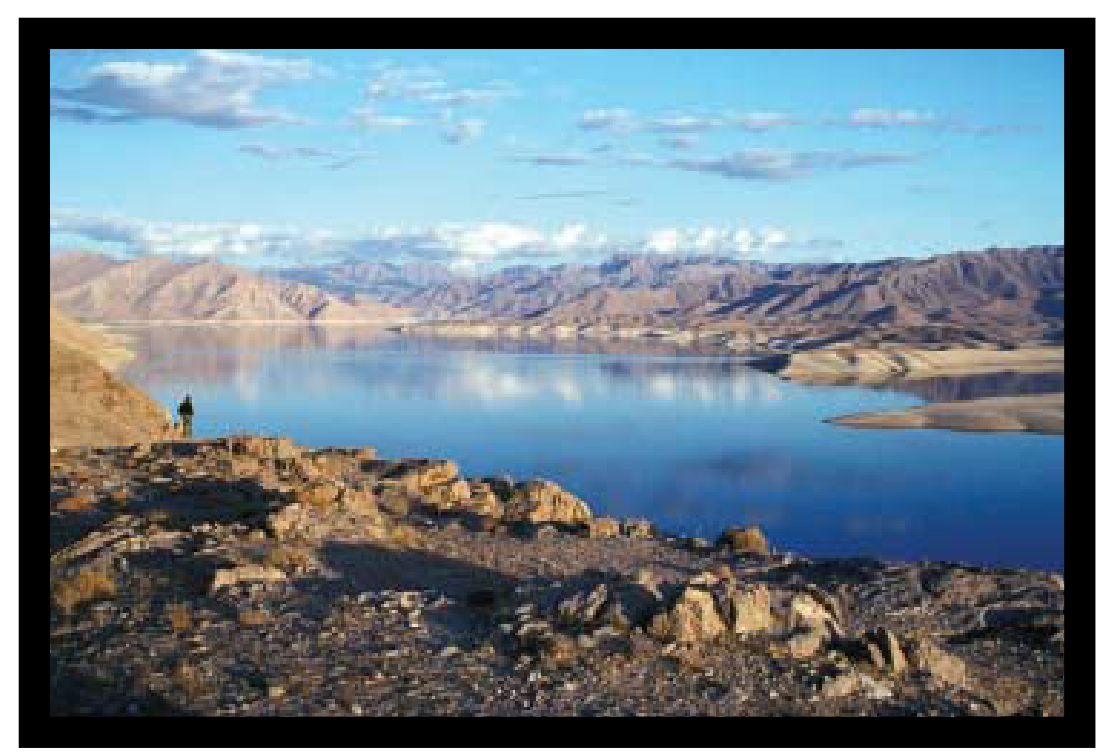

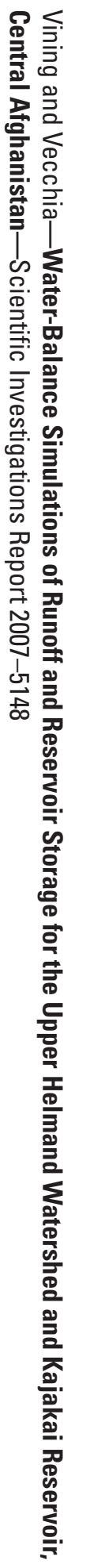

Printed on recycled paper 